\title{
WELFARE AS A FORM OF ENSURING THE SOCIAL SAFETY OF SOCIETY AND AN EFFECTIVE AND SUCCESSFUL TOOL IN ELECTION CAMPAIGNS (THOUGHTS BASED ON THE SITUATION IN CONTEMPORARY POLAND)
}

\author{
ARTUR BANASZAK ${ }^{1}$ \\ University of Euroregional Economy in Józefów (Warsaw, Poland)
}

\begin{abstract}
Welfare in its narrow understanding means the state's material help given to the members of society. It also may be understood as the whole of the state's activities aimed at multi-level support for various social groups. The aim of this paper is to show different elements of material help given to society by the state which help society to meet social security. Also, the findings based on some examples of the current Polish history show how this kind of state's support may help politicians to gain success in elections. The author argues that the same reality, i.e., social help, may be used for people's welfare, however, it may be also used to obtain political goals. It must be noticed that using welfare for political goals often happens the situation when electoral promises are not necessary implemented after a particular party wins the election. To achieve the main purpose of this research the method of analysis was applied. Today, welfare can be used in both ways - as a form of ensuring the social safety of society and as an effective and successful tool in election campaigns.

KEYWORDS: welfare, social security, social help, election campaign, "pork barrel", "electoral sausage”.
\end{abstract}

JEL CODES: I 38.

DOI:

\section{Introduction}

The term 'welfare' may be understood in different ways. First of all, in its narrow meaning, it is material help given by the state to its members of society. In fact, welfare may be given to any member of society, but practice shows that it is focused on the members who are poor or because of any other reasons are not able to deal with their basic human needs (Bulloc, Trombley, 1999: 919). It also may be understood as the whole of the state's activities aimed at multi-level support for various social groups or all types of benefit offered to people as social help. The main goal of such state's support is focused on satisfying the needs of society and ensuring its social safety.

The idea of welfare (all kind of help and support provided by the state to people) may be used by the governments or political parties as an effective and successful tool in election campaigns. Politicians and political parties, especially during the election time, are delivering to people different kind of promises regarding social help. The real help or at least the promises for help may be used as "a pork barrel" or "electoral sausage". And, as many examples from history prove, it helps politicians to gain people's votes and eventually win the elections. Research hypothesis: There are many areas of help given by the state and by the government to the members of society. This help may have a form of material support or may be implemented in any other way, such as free housing, feeding or other. It should be assumed that welfare understood as any form of state's help to people can be used in two different ways. First of all, it is a tool to

1 Artur Banaszak - Alcide De Gasperi University of Euroregional Economy in Józefów - Warsaw (Poland), Lecturer at the University of Euroregional Economy in Józefów (Poland), social and security science 
meet the basic human needs and to secure the feeling of social safety among society members. Secondly, it may be a very powerful political tool, which can help politicians to gain support and consequently choose it during the elections.

The aim of this investigation is to show different elements of material help given to society by the state which help society to meet its social security. Also, the findings based on some examples of the current Polish history show how this kind of state's support may help politicians to gain success in elections. The author highlights that the same reality, i.e., social help, may be used for people's welfare, however, it may be also used to obtain political goals. It must be noticed that using welfare for political goals often happens the situation that electoral promises are not necessary implemented after a particular party wins the election.

In this paper, the author uses the method of analysis on some provisions of international and national law that focus on satisfying the need of social security. Also, there are analysed some practical activities aimed at helping people who are in need. Furthermore, the programs of political parties in Poland are analysed seeking to distinguish what kind of the social help area is covered by them. Finally, the results of some recent elections in Poland are observed, as well as public opinion surveys and polls.

Research method. To achieve the main purpose of this research the author uses the method of analysis. First of all, the paper analyses the rules and regulations of the Polish social help. Then, we the programs of political parties in Poland are studied to find out what kind of the social help area is covered by them. Finally, the results of some recent elections in Poland are observed, as well as public opinion surveys and polls.

The results of the analyses reveal that welfare understood as the material help given by the government or as all kind of the state's support given to people can be used in two ways - it maybe a tool used to satisfy the needs of society in the social security area or as a tool used during different political or election campaigns which may help to gain votes and win the elections.

\section{Welfare as a form of satisfying the social security of society}

Each and every country should have a social security system which will be able to give society the sense of safety. There are different forms and elements of welfare which are aimed to help people in their everyday life. Society (or at least some of the society's members) expects from the state (understood by them as the government) different kind of help, and in most of cases material help. They expect different types of social support.

The term 'social security' may be understood in different ways. It is "protection of the existential basis of human life, ensuring the possibility of satisfying individual needs (material and spiritual) and fulfilling life aspirations by creating conditions for work and study, health protection and pension guarantees" (Skrabacz, Sulowski, 2012: 7). Social safety maybe also described as some kind of protection against economic and social misery which cause various social risks, such as: sickness, old age or unemployment, and other situations which do not let people to take care of their needs by earnings from work (Such-Pyrgiel, Dziurzyński, 2015: 141, 143-144).

For the purpose of this study, the general definition can be assumed which says that social security is the state's guarantees to satisfy the social needs of people or it is a state (a permanent situation) where members of society have a chance for living and development in proper conditions.

Social security and provision of social security is not an option, but it is reality guaranteed by the provisions of many international and national regulations. Firstly, we need to say that social security is one the basic rights of human beings. In the article 22 of the Universal Declaration of Human Rights, one can read that: "Everyone, as a member of society, has the right to social security and is entitled to realization, through national effort and international co-operation and in accordance with the organization and resources of each State, of the economic, social and cultural rights indispensable for his dignity and the free development of his personality" (United Nation Organization, 1948).

Also, other international regulations talk about social security directly or indirectly describing the areas where the state or international organizations should care for people. Such areas are: employment, education, 
the right to proper heath conditions, protection in the case of sickness, protection in the case of maternity, protection of old people, etc. All these areas are the components of social safety. This kind of descriptions may also be found, for example, in the International Labour Organization document - Convention 102 (Convention from 1952 - entry into force in 1955) concerning minimum standards of social security (International Labour Organization, 1952).

This topic of social security is also present in the European Union regulations and documents. For example, the Charter of Fundamental Rights of the European Union is talking about the right to social security and social assistance. In the article 34 , we can read that: " 1 . The Union recognizes and respects the entitlement to social security benefits and social services providing protection in cases such as maternity, illness, industrial accidents, dependency or old age, and in the case of loss of employment, in accordance with the rules laid down by Union law and national laws and practices. 2. Everyone residing and moving legally within the European Union is entitled to social security benefits and social advantages in accordance with Union law and national laws and practices. 3. In order to combat social exclusion and poverty, the Union recognizes and respects the right to social and housing assistance so as to ensure a decent existence for all those who lack sufficient resources, in accordance with the rules laid down by Union law and national laws and practices" (Charter of the Fundamental Rights of the European Union, 2012). The same document also names some of the areas which should be protected and in this way the sense of social security may be implemented, for example: right to security, right to education, right to work in proper conditions, right of elderly and disabled people or right to health care (Charter of the Fundamental Rights of the European Union, 2012).

In Poland, the guarantee of social security is given to us in the Constitution of the Republic of Poland (article 67) which says that: "A citizen shall have the right to social security whenever incapacitated for work by reason of sickness or invalidism as well as having attained retirement age. The scope and forms of social security shall be specified by statute. A citizen who is involuntarily without work and has no other means of support, shall have the right to social security, the scope of which shall be specified by statute" (The Constitution of the Republic of Poland, 1997). Those general indications are developed in detail in many regulations of the Polish legal system.

To some extent, social security is related to the issue of work. It means that the job is a concept which gives people the sense of social security. Therefore, the most important area of the state's or government's activities should be focused on the job market. Having a job helps in satisfying the basic needs as well as the other needs of higher order. During communism, in Poland, yet also in many other the so-called countries of people's democracy, we experienced something what was called "work coercion". It meant that every person had to work (forced employment). In the 20th century, since 90's, after the systematic changes that shifted to the market economy, finding a job became a problem. Many members of society, due to different reasons, cannot find a job and they stayed unemployed. Therefore, lack of work causes lack of a sense of social security.

There may be different reasons which cause that a person is unemployed. People are not able to work due to some reasons such as:

- old age preventing further efficient work;

- health condition permanently preventing or limiting the possibility of work;

- illness temporarily preventing work;

- unemployment (temporary job loss);

- difficult family situation;

- other random events.

Therefore, there are different kinds of risks and the state (government) is expected to take care of them. It means, that in these cases, some tools and methods should be used which, despite the above-mentioned situation, would help people, give them support and make possible to satisfy their social needs.

In Poland, also in other countries of the world, we use three different methods to implement social safety and security. They are the following: 
- social insurance (insurance method);

- social provision (procurement method);

- social help (care method).

Thanks to the activities related to those three methods, the state takes care of society members and helps them to satisfy their needs. We have here the whole system of social insurance such as pension insurance, disability insurance, sickness insurance, health (medical care) insurance or unemployment insurance. Also, there are other forms of helping people who are not able to deal with everyday life, for example: social work, co-financing in the scope of care and social assistance, health protection, benefits for invalids, other types of benefits or even scholarships. Special help may be granted to people who faced the poverty, who are sick, have large families, etc.

In Poland, social assistance is provided by different institutions on different levels. First of all, it is provided by the state via the main institution the Ministry of Family, Labour and Social Policy. Also, there are some institutions of public administration on the regional and local levels responsible for helping people and providing assistance to them (The Ministry of Family, Labour and Social Policy). To some extent, support is also given by other institutions such as non-profit organizations (Blicharz, 2016; WójtowiczDawid, 2011: 345-355) as well as by the religious organizations such as Catholic Church (Sadłoń, 2015) or other religions' institutions. The rules of social assistance are described in detail in different provisions, especially in the Act on social assistance (Act on social assistance, 2004) of 2004 which has been changed many times since then.

At the beginning, social security was described as a state where a person is getting a chance to live and a chance for his/her development. Thus, there is also the whole area related to the development issue, where the most important is the system of public education. Giving to people an opportunity of getting good quality education, makes a huge difference in their future lives. It will help them in the future to get a good job (and in such way to satisfy their needs themselves). Besides, it will help in their development making possible to be a standard value member of society. There are also other areas of state activities related to the social security issues which are aimed at improving the quality of life. So, using all these forms, tools and methods, the state (government) is able to satisfy human needs - both the basic needs (existence needs: physiological, safety and security needs) as well as the needs of higher order (belongings, esteem and self-actualization needs). In this scope, welfare may be understood as a form of ensuring and satisfying the social safety of society.

\section{Welfare as a tool of political and election campaigns}

Using the concept of welfare as a tool that helps to satisfy human needs is one of the possibilities, as it also may be used for other reasons. The governments or political parties may exploit it as an effective and successful tool during election campaigns. Politicians giving different kind of promises to people may gain their votes and eventually win elections. Therefore, the subject of this research is different elements of material help given to society by the state which help society to meet social security. Based on some examples from the current Poland's political situation, I would like to show how this kind of state's support may help politicians to gain success in election. The members of society have different needs and they are looking how to satisfy these needs. So, they are expecting that at least some needs will be satisfied by the state or by the government. Therefore, upon making their election decision they are considering the promises of politicians given to them during the election and political campaigns.

In the literature, there is a term "pork barrel". In different countries and different languages, this term has a little bit different meaning, but the term pork barrel politics usually refers to spending which is intended to benefit constituents of a politician in return for their political support, either in the form of campaign contributions or votes. In the popular 1863 story "The Children of the Public", Edward Everett Hale used the term pork barrel as a homely metaphor for any form of public spending to the citizenry (The Hindu, 2017). 
Due to my origin, I would like to focus on the meaning that is used in my country - in Poland. In the Polish language we translate this term as an "electoral sausage" (kiełbasa wyborcza) and it means a collective term defining populist forms of gaining support in elections. This expression originated in Galicia at the turn of the 19th and 20th centuries, during the democratization of electoral rights to the Council of State and when, at the request of conservative circles, to the electoral law the principle of openness of voting was introduced. At that time, candidates for deputies in order to gain the support of the social masses organized picnics with free food and drink (mainly sausage and vodka). The phenomenon of serving food at pre-election meetings, although to a lesser extent, also occurred during the Second Polish Republic and the first years of the Third Polish Republic (Kiełbasa Wyborcza - Wikipedia).

Currently, the expression is used in a figurative sense, as an expression of attractive but usually impossible way to fulfil pre-election promises. Usually, typical examples are as follows:

- reducing taxes while increasing social benefits;

- reducing bureaucracy;

- liquidation of corruption;

- improving the efficiency of health care;

- different types of social help.

The "electoral sausage" is addressed primarily to voters who do not have sharp political views, are uneducated or have no knowledge about the operation of economic mechanisms. An example of 'an electoral sausage' addressed to such people is the promise to reduce taxes while at the same time intensifying the social policy of the state.

The political scene in Poland is composed of many larger and smaller political parties yet with the two biggest and the most popular ones: PIS (Law and Justice) and PO (Civic Platform). PO was in power (had majority in Parliament) from 2007 to 2015, winning the election twice. Then, in 2015, the situation changed when PIS got the majority and formed the government. It must be mentioned that PO ruled the country in sort of difficult times (the world crises). Therefore, they introduced many unpopular decisions which were aimed at dealing with difficult economic situation. Many experts believe that thanks to those activities, Poland went out from the world crises in a pretty good shape, however, at the same time a member of the Polish society was getting less individual governmental help. For example, they changed the age of retirement (from 60 (woman) and 65 (men) to 67) or put some limits to social help. Basically, it can be stated that the distribution of public money and provision of different types of public material help was on the very low level. Unsurprisingly, such activities were not so popular among most of society.

Also, during the campaigns (in 2007 and 2011) PO was giving many promises regarding social security. For example, they promised to reduce the PIT and VAT taxes, and to reduce charges related to labour costs, as well as to create more job places and improve the education system (e.g., free textbooks for children at the primary education level). However, most of those promises have been never fulfilled.

During the eight years of PO being in the government, the taxes and labour costs went up, the retirement age was extended and there was a problem with unemployment in Poland. Only kids in the primary education got free textbooks, yet many experts and teachers expressed their negative opinion about the quality of the material.

PIS, as the opposition to PO, went to the presidential election (in 2015) and then to parliament election (in 2015) with the ideas to improve the system of welfare and social help. They knew exactly what people wanted to get and they were promising those things to people.

All these activities (promises and real activities) in the area of social help and support changed a lot the Polish political scene. In 2015, there the presidential election in Poland took place. Bronisław Komorowski (supported by PO), who was on the presidential office since 2010, at the beginning of the election campaign (January 2015) was leading with the result of 64\% among 11 candidates while his biggest opponent - Andrzej Duda (supported by PIS) - had 22\% on that time. During the campaign, in which Andrzej Duda focused on many social needs of society, the advantage of Komorowski began to go down. 
In the election promises of Andrzej Duda there were many issues related to the social security area. In his election programme, A. Duda was taking, among other, about the improvement of the family status by giving extra financial sources $(500+$ program) and opening of free preschools. He promised to improve the health care system in the country and talked about the satiation of old-aged people (about lowering the retirement age and increasing the pensions). Moreover, he was taking about new job places and about activities aimed at increasing the salaries (Komitet Wyborczy - Andrzej Duda).

At the same time, Bronisław Komorowski discussed about the continuation of his work as president, mainly focusing on building national consent, improving external security of the country related to the NATO activities. Though he was taking about the care of families and economy, but his programme was based on the very general ideas without precise and specific solutions (Komitet Wyborczy - Bronisław Komorowski).

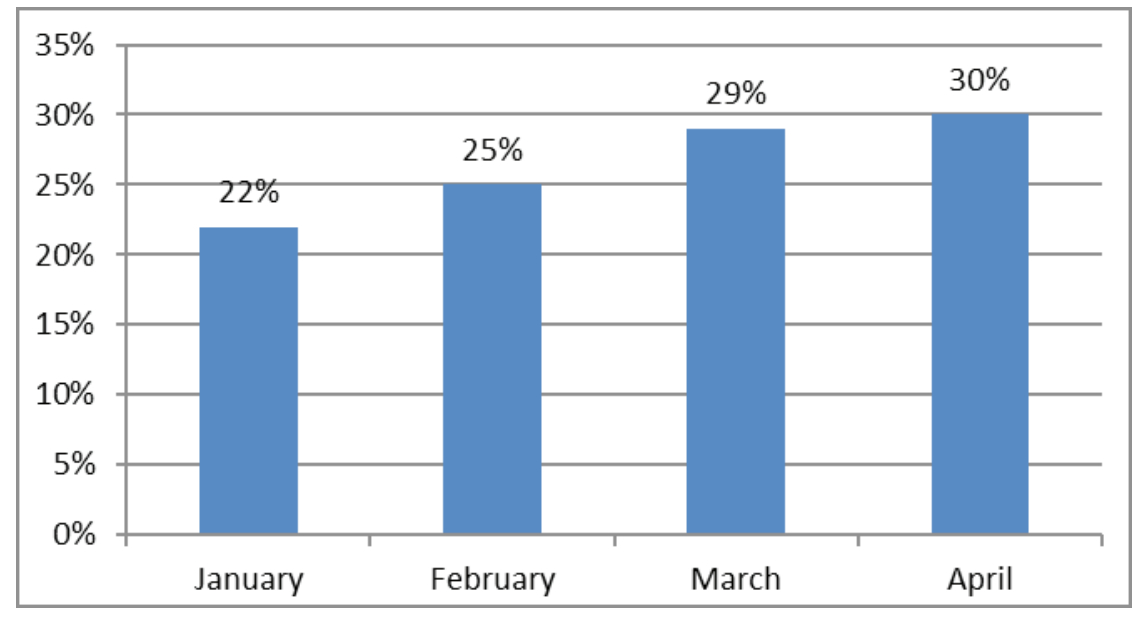

Fig. 1. Survey of the support for B. Komorowski during the 2015 presidential campaign

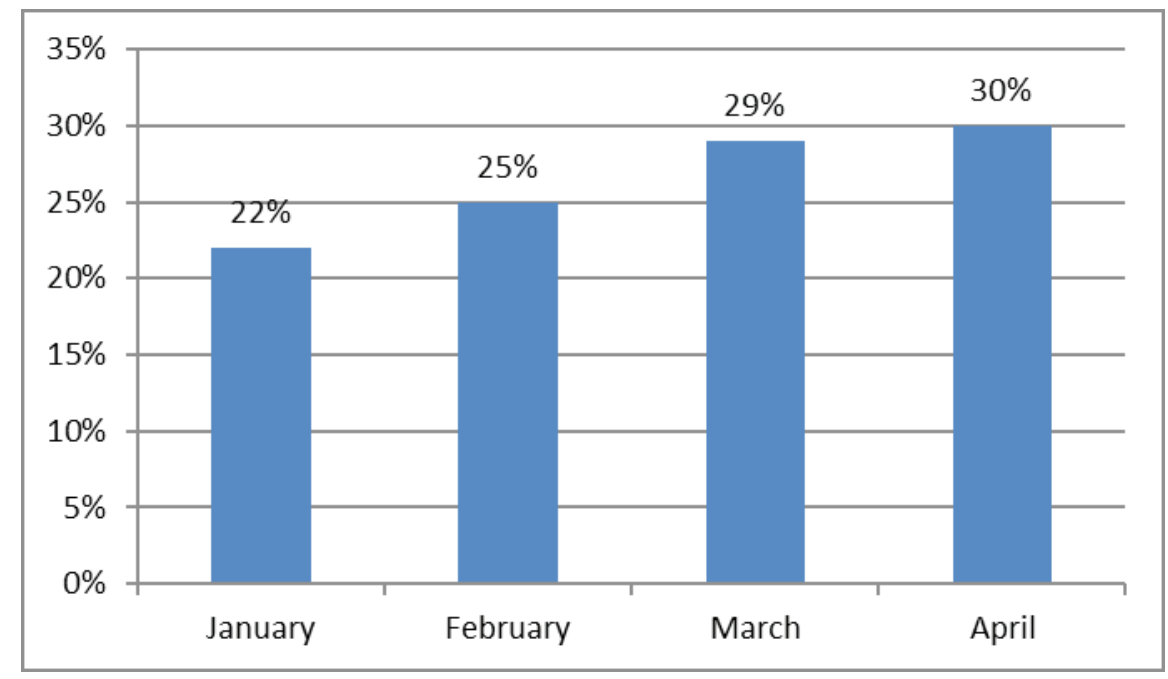

Fig. 2. Survey of the support for A. Duda during the 2015 presidential campaign

Source: developed by the author based on the data taken from different public opinion research institutions.

The way of conducting the presidential campaign and the areas that covered the programmes of each candidate led to the situation that people changed their electoral preferences and with time, more and more people started to support Andrzej Duda. In the first round, which took place on $10^{\text {th }}$ May 2015, the results were different from the previous polls. A. Duda won the first round with $34.76 \%$, while B. Komorowski 
got only 33.77\%. (Państwwowa Komisja Wyborcza, 2015a). Two weeks of the campaign before the second round $\left(24^{\text {th }}\right.$ May 2015) did not make much difference and the final result gave the presidential seat to Andrzej Duda who won with the support of $51.55 \%$ to the $48.45 \%$ got by B. Komorowski (Państwwowa Komisja Wyborcza, 2015b).

The presidential election was the beginning of big changes on the political scene in Poland. PIS used the similar tactics during the parliamentary election which took place a few months later, on $25^{\text {th }}$ October 2015. PIS was giving to people many promises regarding the area of social security and social help. They used welfare to get support from society. In their election programme, there were some ideas similar to those given by Andrzej Duda. The programme of this political party included so many issues but during the meetings with people and on the election spots they focused on the following things:

- changes of the retirement age - going back from the age of sixty-seven, which was introduced by PO, to the age of sixty for woman and sixty-five for man;

- the program FAMILY 500plus - a program according to which every family having more than one child under eighteen-year-old gets 500 PLN every month, or families with low income and only one child also get every month;

- increased sum of the minimum pension from 880 PLN to 1078 PLN;

- changes in the education system - going back to the age of seven for starting the primary education as well as changing the educational system on the primary and secondary level (Prawo i Sprawiedliwość, 2014).

Those promises and focusing on social issues, similar like in the presidential election, led to huge success of this political party in the parliamentary election in 2015. PIS got $37.58 \%$ which gave them $51 \%$ of seats in Polish Parliament (Państwwowa Komisja Wyborcza, 2015c).

Table 1. The changes in electoral preferences between 2007-2018 in Poland

\begin{tabular}{|l|l|l|}
\hline \multicolumn{1}{|c|}{ YEAR } & \multicolumn{1}{|c|}{\begin{tabular}{c}
\multicolumn{1}{|c|}{ PO } \\
(Civic Platform)
\end{tabular}} & \multicolumn{1}{c|}{ PIS (Law and Justice) } \\
\hline Election 2007 & $41.51 \%$ & $32.11 \%$ \\
\hline Election 2011 & $39.18 \%$ & $29.89 \%$ \\
\hline Election 2015 & $24.05 \%$ & $37.58 \%$ \\
& $(30 \%$ of seats in Parliament) & $(51 \%$ of seats in parliament) \\
\hline Election poll - May 2018 & $25 \%$ & $33 \%$ \\
\hline
\end{tabular}

Source: the author's calculation based on the data taken from different public opinion research institutions and on the result of the State Electoral Commission.

Also, before this year election to the local government (2018) and the next year election to the Polish Parliament (2019), the government has been delivering next social promises, such as:

- lower charges related to labour costs for small business;

- special programs for senior citizens;

- special programs related to social housing;

- 300 PLN per year for each school child - to buy things necessary for school (Prawo i Sprawiedliwość, 2018).

Experts are arguing about the cost of all promises and real help given to people. Some of economists want to prove that Poland cannot afford such big distribution and giving away. However, most of the society members are happy and have very positive opinion about the current situation. And therefore, many of them declare that they will still vote for PIS (Ćwiklak, 2016). 


\section{Conclusions}

Welfare means the state's material help given to its society members and all state's activities aimed at multi-level support for various social groups. So, it can mean all types of benefit given to people in the form of social help. The main goal of this support is focused on satisfying the needs of society and ensuring the social safety of society. Yet it may be also used by the governments or political parties as an effective and successful tool in election campaigns. Giving different kind of promises to people may help to gain their votes and eventually win various elections. In Poland, social security is guaranteed by our legal system. The Polish citizens receive different type of social help given by the state and thanks to this support many of them have the sense of social security.

Social security in Poland in basically related to the area of work and job. Having a job gives guarantees that a person will be able to meet the basic needs and his or her sense of social security will be satisfied. But in situations when people cannot work, the state has different tools and methods which help to ensure their social needs. Besides, there are other forms of help which cover different areas of human existence. It should be noted that social help in Poland is implemented not only by state institutions but there are also many other organizations, including NGOs, which cover different human needs. The current situation in Poland shows that social help is implemented in quite a good way, though there are some areas which should be improved. The most important here is help and support for disabled people. In Poland, we have some tools to support this social group but the sense of social security of disabled people is rather low.

The social security issue can be used also by politicians during political and election campaigns. The above-mention examples taken from the current history of Poland demonstrate that social offers can be used as a "pork barrel" or "electoral sausage". Giving to people only promises for different kind of support is almost a guarantee of winning election. Though some of these promises are implemented, but many of them stay untouched and politicians forget about them until next elections. This means that members of society lost trust in certain political parties. Later, another political party comes with even more promises and the political situation of the country is not stable anymore.

There is one more danger or risk related to these social promises. To implement all the promises or at least some of them, the state needs financial resources. Very often, these promises are given without careful analysis of the state budget and its financial situation. Realization of some social promises can increase the budget deficit.

In addition, if the state is only giving a lot of help to people, it has bad influence on activities of citizens. People who are getting too much, are not active and just wait to receive the help. It creates the situation, when people are not able to satisfy their social needs by themselves and have very great demands on the state. Their sense of social safety depends on the state's activities. Consequently, they have lost their social independence and the ability to take care of themselves and their families. Their election choices depend on promises, i.e., on those who offer more not those who would be better for the country.

Therefore, today welfare can be used in both ways - as a form of ensuring the social safety of society as well as an effective and successful tool in election campaigns.

\section{References}

Blicharz, J. (2016). Fundacje-wybrane zagadnienia. Wrocław: E-Wydawnictwo. Prawnicza i Ekonomiczna Biblioteka Cyfrowa Wydział Prawa, Administracji i Ekonomii Uniwersytetu Wrocławskiego.

Komitet Wyborczy - Bronisław Komorowski. Bronisław Komorowski - nasz Prezydent. Materiał wyborczy Komitetu Kandydata na Prezydenta RP Bronisława Komorowskiego. Available at: http://slawomirpiechota.pl/wp-content/uploads/2015/02/Publikacja_Bronislaw-Komorowski-Nasz-Prezydent.pdf [Accessed May 20, 2018].

Bullock, A., Trombley, S. (1999). The New Fontana Dictionary of Modern Thought. Third Edition. New York: HarperCollins.

Charter of the Fundamental Rights of the European Union. (2012). Official Journal of the European Union of, 26.10.2012, C 326/02. 
Ćwiklak, D. (2016). Krótka finansowa kołdra PiS. Za „dobrą zmianę” zapłacimy wyższymi podatkami. Newsweek Polska, 27.04.2016. Available at: http://www.newsweek.pl/opinie/gospodarcze-obietnice-pis-koszt-obietnic-wyborczych-pis-,artykuly,384739,1.html [Accessed May 20, 2018].

International Labour Organization. (1952). Convention 102 concerning minimum standards of social security. Available at: http://www.ilo.org/dyn/normlex/en/f?p=NORMLEXPUB:12100:0::NO::P12100_ILO_CODE:C102 [Accessed May 20, 2018].

Państwowa Komisja Wyborcza. (2015a). Obwieszczenie Państwowej Komisji Wyborczej z dnia 11 maja 2015 r. o wynikach głosowania i wyniku wyborów Prezydenta Rzeczypospolitej Polskiej, zarządzonych na dzień 10 maja 2015 r. Available at: http://prezydent2015.pkw.gov.pl/pliki/1_Obwieszczenie.pdf [Accessed May 20, 2018].

Państwowa Komisja Wyborcza. (2015b). Obwieszczenie Państwowej Komisji Wyborczej z dnia 25 maja 2015 r. o wynikach ponownego głosowania i wyniku wyborów Prezydenta Rzeczypospolitej Polskiej. Available at: http:// prezydent2015.pkw.gov.pl/pliki/1432571989_obwieszczenie.pdf [Accessed May 20, 2018 ].

Państwowa Komisja Wyborcza. (2015c). Wyborydo Sejmu i Senatu Rzeczypospolitej Polskiej 2015. Wyniki wyborów do Sejmu RP. Available at: http://parlament2015.pkw.gov.pl/349_Wyniki_Sejm [Accessed May 20, 2018 ].

Prawo i sprawiedliwość (2014). Zdrowie - Rodzina - Praca. Program Prawa i Sprawiedliwości. Available at: http://pis. org.pl/document/archive/download/128 [Accessed May 20, 2018].

Prawo i Sprawiedliwość. (2018). „,Dobra Zmiana” wymaga ciagłego działania. Available at: http://pis.org.pl/aktualnosci/dobra-zmiana-wymaga-ciaglego-dzialania [Accessed May 20, 2018 ].

Sadłoń, W. (2015). Postuga charytatywna Kościoła Katolickiego w Polsce. Raport z pierwszego ogólnopolskiego badania kościelnych instytucji oraz organizacji charytatywnych. Warszawa: Instytut Statystyki Kościoła Katolickiego SAC. Available at: http://www.caritas.pl/wp-content/uploads/2015/12/ISKK_Dzialanosc_charytatywna_ KK_2015_.pdf [Accessed May 20, 2018].

Skrabacz, A., Sulowski, S. (2012). Bezpieczeństwo społeczne. Pojęcia, uwarunkowania, wyzwania. Warszawa: Elipsa.

Such-Pyrgiel, M., Dziurzyński, K. (2015). Bezpieczeństwo społeczne. Leksykon Bezpieczeństwo. Wybrane pojęcia. Rd. P. Chodak. Józefów: WSGE Publishing House.

The Constitution of the Republic of Poland. (1997). Journal of Laws, No 78, Item 483 (Dz.U., Nr. 78 poz. 483 ). Text in English language available at: http://www.sejm.gov.pl/prawo/konst/angielski/kon1.htm [Accessed May 20, 2018].

The Hindu. (2017). What is 'Pork barrel' in Economics? Available at: https://www.thehindu.com/opinion/op-ed/whatis-pork-barrel-in-economics/article19466625.ece [Accessed May 20, 2018].

The Ministry of Family, Labour and Social Policy. System of Social Assistance in Poland. Available at: https://www. mpips.gov.pl/en/social-assistance/ [Accessed May 20, 2018].

Komitet Wyborczy - Andrzej Duda. Umowa programowa Andrzeja Dudy z Polakami. Rodzina - praca - bezpieczeństwo - dialog. Material wyborczy Komitetu Kandydata na Prezydenta RP Andrzeja Dudy. Available at: http://www.jedrysek.eu/articles/UMOWA_PROGRAMOWA.pdf [Accessed May 20, 2018 ].

United Nation Organization. (1948). Universal Declaration of Human Right. Available at: https://www.ohchr.org/EN/ UDHR/Documents/UDHR_Translations/eng.pdf [Accessed May 20, 2018].

Ustawa z dnia 12 marca 2004 r. o pomocy społecznej. (2004). Dz.U., Nr. 64, poz. 593 z poźn. zm. Act of 12th March 2004 on social assistance. Journal of Laws, No 64, Item 593 with amendments.

Wikipedia - wolna encyklopedia. Hasło: Kiełbasa wyborcza. Available at: https://pl.wikipedia.org/wiki/Kiełbasa_ wyborcza [Accessed May 20, 2018].

Wójtowicz-Dawid, A. (2011).Organizacje pozarządowe i ich rola w realizacji spójności społeczno-ekonomicznejwybrane aspekty prawne. Nierówności Społeczne a Wzrost Gospodarczy, Vol. 18, p. 345-355. Rzeszów: Katedra Mikroekonomii Uniwersytetu Rzeszowskiego. 


\title{
GEROVË KAIP VISUOMENÉS SOCIALINIO SAUGUMO FORMA, BE TO, VEIKSMINGA IR SËKMINGA RINKIMU KAMPANIJOS PRIEMONE (REMIANTIS DABARTINE PADE T IM I LE NKIJOJE)
}

\author{
ArTUR BANASZAK \\ Euroregioninės ekonomikos universitetas Jozefove (Varšuva, Lenkija)
}

\section{Santrauka}

Gerove siauraja prasme suprantama kaip visuomenès nariams teikiama materiali valstybės pagalba. Ji gali būti suprantama ir kaip veikla, kuria siekiama teikti įvairią paramą ịvairioms socialinėms grupèms. Pagrindinis tokios valstybės paramos siekis nukreiptas ị visuomenès poreikių tenkinimą ir socialinio saugumo užtikrinimą. Tiesa, vyriausybès ar politinès partijos ją gali naudoti ir kaip veiksmingą sėkmingos rinkimų kampanijos priemonę: pažadèti kažką žmonèms, siekdamos pelnyti jų balsus ir galiausiai laimèti rinkimus. Tokiu gerovės pasitelkimo pavyzdžiu gali būti dabartinė Lenkija.

Tyrimo hipotezè: valstybė ir vyriausybẻ teikia visuomenės nariams pagalbą daugelyje sričiu. Tai gali būti materiali ar bet kuriuo kitu būdu teikiama parama, pavyzdžiui, nemokamas būstas, maitinimas ar kt. Taigi gerovė, suprantama kaip bet kuri valstybès pagalba žmonèms, gali būti išnaudojama dviem būdais. Visų pirma siekiant patenkinti pagrindinius žmonių poreikius ir suteikti visuomenès nariams socialinės apsaugos jausmą. Antra, tai gali būti galingas politinis ịrankis, politikams siekiant gauti visuomenès paramą rinkimuose.

Šio darbo tikslas: atskleisti ịvairius valstybės materialinės paramos visuomenei elementus, kurie užtikrina socialinę apsaugą. Be to, remiantis šiuolaikinès Lenkijos istorijos pavyzdžiais, straipsnyje atskleidžiama, kaip tokia valstybès parama gali padèti politikams laimèti rinkimus. Siekiama atkreipti dèmesị ị tai, kad ta pačia realybe - socialine pagalba - gali būti pasinaudota ir politiniais tikslais. Reikia pastebèti, kad gerovès išnaudojimas politiniais tikslais - dažnas reiškinys.

Siekiant pagrindinio tyrimo tikslo taikytas analizès metodas. Visų pirma straipsnyje analizuojamos Lenkijos socialinès pagalbos teikimo taisyklès ir šio proceso reguliavimas. Be to, analizuojamos politinių partijų programos Lenkijoje, apžvelgiama, kokias socialinès pagalbos sritis jos apima. Galiausiai analizuojami keleto pastarųų metų rinkimų Lenkijoje rezultatai ir viešosios nuomonės apklausos.

Išvados: gerovė suprantama kaip visokeriopa nauda žmonėms socialinės paramos srityje, ja naudojamasi, siekiant patenkinti visuomenès narių socialinius poreikius ir užtikrinti socialinę apsaugą bei siekti politinių tikslų. Socialinè apsauga Lenkijoje iš esmès susijusi su darbo sritimi. Darbo turèjimas daugeliui Lenkijos visuomenès narių suteikia socialinio saugumo jausmą. Tačiau susiklosčius situacijai, kai žmonès negali dirbti, valstybe turi įvairių priemonių ir metodų, kurie padeda tenkinti socialinius poreikius. Yra ir kitu pagalbos formų, apimančių ịvairias žmonių egzistavimo sritis.

Lenkijoje teikiama parama yra gana aukšto lygio. Vis dèlto socialinès apsaugos sritị politikai išnaudoja ir politinèse, ir rinkimų kampanijose. Remiantis dabartinės Lenkijos pavyzdžiais, galima paminèti atveji, kai socialiniai pasiūlymai gali būti naudojami kaip „rinkiminè dešra“. Duodami ir ịgyvendinami pažadai, teikiant žmonėms ịvairią paramą, iš esmès užtikrina rinkimų sèkmę. Taigi šiandien gerovè gali būti išnaudojama ir kaip visuomenès socialinio saugumo užtikrinimo forma, ir kaip veiksminga sẻkmingos rinkimų kampanijos priemonè.

PAGRINDINIAI ŽODŽIAI: gerové, socialine apsanga, socialine pagalba, rinkimu kampanija.

JEL KLAISIFIKACIJA: I 38.

Received: 2018.07.17

Revised: 2018.08 .20

Accepted: 2018.09.02 